\title{
Analysis of Incomeand Expenditure Pattern of Rural Households in Jema'a Local Government Area of Kaduna State, Nigeria
}

\author{
Manza, E. A. G \\ Department of Agricultural Economics and Extension \\ Kaduna State University \\ Kafanchan Campus, Kafanchan, Kaduna State \\ Nigeria \\ Garba, T.K. \\ Department of Development Finance \\ Central Bank of Nigeria, Jos Branch, Jos \\ Nigeria
}

\begin{abstract}
The paper aims to compare the income of households' primary farmers with those of secondary farmers, to examine the expenditure pattern among the rural households and analyze the factors influencing the consumption pattern of rural householdsin Jema'a Local Government Area of Kaduna State, Nigeria. A total of 149 households were selected through multistage sampling procedure. Primary data was collected using a structured questionnaire. Descriptive statistics involving frequencies, mean, standard deviation and percentages were used. In addition, t-test, ANOVA, Regression Analysis and Duncan range test were carried out. The result showed that of the 149 households studied, $74.5 \%$ had farming as primary occupation while $25.5 \%$ had other occupations as primary occupation. Comparing the income and expenditure of both groups showed that there were significant differences suggesting that the households spent more than their declared incomes. This could mean that other sources of income might have not been captured. Looking at the spending habit of the households, the results showed that at 5\% probability, there was a significant difference between the expenditure in the different categories of food, social, education, house maintenance, transportation, farm, health and miscellaneous. The Duncan Range Multiple test showed that the highest expenditure was on food followed by education, transport, farm inputs, house maintenance,health, social and miscellaneous expenses. The differences in the expenditure on education, social, health and farm were significant at 1\% probability. We conclude that farming isprofitable since the income from farming and the income from other jobs were significant at $5 \%$ probability.
\end{abstract}

Keywords: Income; Expenditure Pattern; Rural Households;Consumption;Primary Occupation;Descriptive Statistics; t-test; ANOVA; Regression Analysis and Duncan range

\section{Introduction}

Agriculture is the main source of income in rural Nigeria, and the growth rates of the agriculture sector have not been quite impressive (Dauda, 2003). Trading, weaving, carving, subsistence farming etc., represent other secondary economic rural activities.

A study by IFAD (2011) established that Nigeria's rural economy is largely agrarian as agriculture is still the mainstay of the agrarian economy contributing about 45 percent of the GDP. Agriculture employs about two thirds of the country's total labour force and provides a livelihood for about 90 percent of the rural population. Income has been variously defined. For example, income has been defined as money that an individual or business receives in exchange for providing a good or service or through investing capital. Income is used for financing day to day expenditure. (Investopedia accessed $4^{\text {th }}$ August, 2016). The American Heritage Dictionary of the English Language (2011) defined income as the amount of money or its equivalent received during a period of time in exchange for labour or services, from the sale of goods or property, or as profit from financial investments. Income means the maximum amount an individual can spend during a period without being any worse off. Income (and not the GDP) is the engine that drives an economy because only it can create demand. However, for households and individuals, "income is the sum of all the wages, salaries, profits, interest payments, rents, and other forms of earnings received in a given period of time."(Wikipedia accessed 4/8/2016). 
The National Bureau of Statistics (NBS, 2010) classified income into four main categories namely: agricultural enterprises (growing crops or raising livestocks), non- agricultural enterprises (a small shop or other form of household self-employment), wage or salary income (having an employer), and other, non-labour income. Of the four main categories of income sources, on average, Nigerian households have two sources of income, with over 80 percent of all households reporting two income sources. Very few houses reported income from all four sources. Among the rural households, four out of five households were engaged in some agricultural activity - either farming crops or maintaining livestock(NBS,2010). These households tended to be involved in other activities.

According to Ojeleye (2015) consumption pattern describes the variation in goods and services consumed. An individual's decision on what range and type of food commodity to consume is influenced greatly by income and other factors such as social norms. The proportion of the total income spent on consumption is referred to as the average propensity to consume (APC). The marginal propensity to consume (MPC), on the other hand, is the increase in consumption expenditure per unit increase in total income.

Basumatary (2015)says consumption is an integral part of life. However, the dynamic nature of human wants, gives consumption a dynamic character. Variations in consumption are visible in different societies, as there exists a difference in environment, social, economic and cultural contexts. In addition, there has been a rapid change in the ladder of economic status of different social groups or communities. The determinants of the economic status of a society are its per capita income, the standard of living, the level of consumption etc. While the increase in per capita income and per capita consumption expenditure are some of the macro level indicators of development, their distributions are some of the macro level indicators of development. The distribution of household expenditure is a micro level indicator.

The level of spending on basics - food, fuel and clothing - increases with wealth, but the budget share falls, as would be expected for goods that are considered economic necessities. (Banks and Leicester,2014). According to Basumatary (2015) the level of consumption expenditure of the tribal people in the rural areas basically depends directly or indirectly on the amount of output they can produce from their farm lands or by selling their labour in the agricultural sector. As such, their level of consumption is generally determined by the subsistent agricultural production.

Basumatary (2015) also posits that a household is a distinctly identified unit of consumption of goods and services and the measures of household consumption expenditure is the single most significant indicator of access of households to the basket of goods and services, their level of living and economic well-being, as well as disparities thereof. Household consumption expenditure (HCE) is most easily understood as expenditure incurred by households on consumption of goods and services used for the direct satisfaction of individual needs and wants or the collective needs of members of the community and not for further transformation in production.

Standard economic models state that it is consumption of goods and services that provides individuals or households with utility. For many households, consumption will not be equal to income, and hence the two measures may provide different pictures of economic well-being. The elderly population is a group for which this is particularly relevant for two reasons. First, the dissaving of any financial wealth accumulated over their pension annuities or earned income alone. Second, however, any uncertainties they might have about future needs (such as health care or long term care costs) or even their remaining length of life may mean that people are unwilling to dissave so much, perhaps even consuming less than their pension income and choosing instead to add to their financial wealth. (Banks and Leicester,2014). Consumption expenditure pattern is an important indicator of economic status and living standards of households. Therefore, the various food and non-food consumption options depend on the availability of goods and services. (Basumatary, 2015)

This study attempts to analyze income and expenditure pattern of some of the rural households in Jema'a LGA of Kaduna State. Through this study, an effort will be made to make a special enquiry on the income and consumption expenditure pattern on food and non-food items at the household level. The reason being that, in the contemporary world the consumption habits and pattern are determined by a complex set of socio-economic, cultural, religious, psychological, ethical and environmental factors. Therefore, the consumption pattern of a rural household distinctly reveals its financial position (income) as well as its standard of living and poverty level. Moreover, the study assumes importance because no similar study is known to have been carried out in the area. The main objective of this study is to undertake an analysis of the income and expenditure pattern of rural households in Jema'a LGA of Kaduna State.

The specific objectives are to:

a. compare the income of households whose primary occupation is farming with those whose primary occupation is other jobs than agriculture; and

b. examine the consumption (expenditure) pattern of both categories of households. 


\section{Literature Review/Conceptual Framework}

In consumer theory 'income' is another name for the "budget constraint." An income can be spent on one or more goods and services with varying quantities of such goods and services. All of such income can either be spent all on goods and or services or part of it can be saved. Income-consumption relationship had been a subject of many studies over the years using empirical data for different countries at different times. Consumption expenditure being a major human activity has always elicited the interest of social scientists for the fact that it is a major determinant of the National aggregate demand. As a financial planning tool and a primary indicator of economic well-being, household consumption expenditure has become very important in fiscal policy making by the fiscal authorities. Consumption research has thus evolved over the years but basically hinged on five fundamental theories of consumption which are; Keynes Absolute Income Hypothesis (AHI) of 1936, Dusenberry's Relative Income Hypothesis (RIH) of 1949, Modigliani's Life Cycle Hypothesis (LCH) of 1949, Brown's Habit Persistence Hypothesis (HPH) of 1952, and Friedman's Permanent Income Hypothesis (PIH) of 1957. These theories have over the years defined researches into consumption function which describes the relationship between income and consumption.

Adedotun (1978) shows that consumption and per capita income positively correlated just as Ofwona (2013) uses the method of ordinary least squares to show that household consumption expenditure is determined by income in Kenya. That study revealed that consumption is determined by income and the Absolute Income Hypothesis (AIH) worked during 1992-2011 in Kenya.

Nwabueze (2009) investigates the relationship between gross domestic product and personal consumption expenditure and found that an increase in gross domestic product had no significant effect on the personal consumption expenditure in Nigeria using data for the years 1994-2007. On the other hand, a study by Uwajaren (1977) relates consumption expenditure in Nigeria to Friedman's Permanent Income Hypothesis and showed that consumption was a function of current and permanent income. In microeconomic theory, actual expenditure equals to total output, while aggregate demand is considered as aggregate planned expenditure. Household consumption expenditures, investment, public expenditures and the net export are the components of the total output or GDP.

Alimi (2013) investigates the relationship between consumption expenditure and income according to Keynes' Absolute Income Hypothesis in Nigeria. He established that as income increases, the average propensity to consume (APC) is reduced as Keynes indicated. But in the long run although the marginal propensity to consume (MPC) is less than one, it is not stable. Studies by Deaton (2001) and Zeldes (2005) identify several factors as very important in determining consumption. Such factors include savings, unanticipated shocks, attitude of consumers, presence of liquidity constraints, etc.

In Friedman's Permanent Income Hypothesis (PIH), it is assumed that income ' $\mathrm{Y}$ ' has two components: a permanent component (Yp) and a transitory component (Yt). In agreement, consumption expenditures have two components, i.e. permanent consumption $(\mathrm{Cp})$ and transitory consumption $(\mathrm{Ct})$. Here, consumers plan to maximize their lifetime consumption based on the permanent component of consumption. The total consumption would be equal to permanent consumption and total consumption relates to all other factors. Many studies used this linear relationship which is expressed thus: $\mathrm{Ct}=\alpha+\beta \mathrm{Y}_{\mathrm{t}}+\mathrm{C}_{\mathrm{t}-1}+\sum \mathrm{t}$.

Where $C_{t}$ is total private consumption at time $t, Y_{t}$ is disposable income at time $t, \alpha$ is autonomous consumption, $\beta$ is marginal propensity to consume, $\mathrm{C}_{\mathrm{t}=1}$ is one period lagged of consumption.

In reality however, there are several factors that determine consumption and for the purpose of this study only the relationship between income and consumption would be investigated. Obviously, there is the need to tailor specific studies to geographical locations in Nigeria as is being done in this study.

\section{Methodology}

\subsection{Study Area and Data}

The study area is Jema'a Local Government Area of Kaduna State, Nigeria. It is one of the 23 LGAs of the State with an area of 1,661 km located between latitude $9010^{\prime}$ and $9030^{\prime} \mathrm{N}$ and longitude $8000^{\prime}$ and $8030^{\prime} \mathrm{E}$. The Local Government is bounds in the East by Kagoro in Kaura LGA, in the North by Madakiya and UngwarRimi Districts of Zangon Kataf LGA, in the West by Jaba LGA and in the South by Nassarawa State and in the South-East by Sanga LGA respectively. The study area has witnessed a tremendous growth in population in the last 30 years. It had a population of 278,735 with an annual growth rate of $3 \%$ in the state (NPC, 2006). The 2016 projected population was about 385,833 people. Presently, it has twelve political wards, namely: Jagindi, Godogodo, Atuku, Gidan-Waya, Maigizo, Kaninkon, Kagoma, Asso, Kafanchan 'A', Kafanchan 'B', Bedde and Takau. 
The area has two distinct seasons, a wet season (April -October) and a dry season (November-March) each year. Rainfall occurs in the months of April to October with a peak in August. The mean annual rainfall is about $1800 \mathrm{~mm}$, and the mean monthly temperature is $25^{\circ} \mathrm{C}$, while the relative humidity is about $62 \%$. The orographic effects of the JosPlateau and the Kagoro hills have positive influence on the weather influencing rainfall, temperature and relative humidity.

The main type of soil is the ferruginous tropical soil which is related to the climate, vegetation, lithology and the topography of the area. The relief is relatively flat and undulating and it influences the drainage pattern of the area.

Agriculture is the main source of livelihood in the area. The agricultural activities can be categorized into crop production, animal husbandry, marketing of agricultural produce, agro processing and food vendors such as baking of cowpea cakes(kosai). Major crops grown include: maize, sorghum, cowpea, groundnuts, vegetables and fruits such as banana, oranges and oil palm. The animals reared include: cattle, sheep, goats pigs and poultry.

A multi-stage and random sampling technique was used to collect the data from 240 respondents from 6 (Atuku, Takau, Kaninkon, Kagoma, Kafanchan "A" and Godogodo) communities in the LGA using a structured questionnaire administered by trained enumerators. A total of 200 questionnaires after some households were dropped due to incomplete data on them were used for the analysis.

\subsection{DataAnalysis}

Descriptive statistics including frequency, mean, standard deviation and percentages were used. Furthermore, the paired sample t-test and independent sample t-test, Analysis of Variance (ANOVA), Correlation Analysis, Regression Analysis and the Duncan Range Test were used for further analysis.

The paired sample t-test is a hypothesis test that is used to compare the mean of two populations when each element of a population is related to an element from the other one. This procedure enables the researcher to compare the mean of two related and dependent populations. This would enable the researcher make comparison and examine the difference between two independent populations based on a sample containing numerical data. This procedure is also applied when the result of the first group is not independent of the second group. This should happen when we assume that the sample difference score is randomly and independently drawn from an approximate normal population.

The decision criterion is reject Ho if the calculated value for the $t$-test is greater than the table value of the $t$-test $\left(t_{x / 2}, n-\right.$ 1), otherwise accept. Using SPSS, if the p-value (sig value) is less than 0.05 reject the null hypothesis, otherwise accept (Abdulazeez et al., 2002 and Alabi, 2013).

The Analysis of Variance (ANOVA) is a collection of statistical models used to analyze the differences between group means and their associated procedures (such as "variation" among and between groups). It is used to evaluate the difference in average scores measured on a continuous scale among one or more characteristics defined by categories. The one-way ANOVA has the advantage of testing whether there are any differences between the groups with a single probability associated with the test. The hypothesis tested is that all groups have the same mean. The required statistical model is given as:

$\mathrm{Y}_{\mathrm{ij}}=\mu+\alpha_{\mathrm{i}}+\epsilon_{\mathrm{i}}$

Where, $\mu$ is the grand mean

$\alpha_{\mathrm{i}}$ is the effect of treatment

$\epsilon_{\mathrm{ij}}$ is the error term assumed to be normally distributed

The interest is whether the calculated F-ratio is greater or less than the F table at a chosen level of significance. If the Fratio calculated is greater than the F-table, the null hypothesis is rejected.

Table 1: Comparison of Income of Primary Farmers and Secondary Farmers

\begin{tabular}{|l|l|l|l|l|l|}
\hline & Source & $\mathrm{N}$ & Mean & Std. Deviation & Std. Error Mean \\
\hline \multirow{2}{*}{ Income } & primary & 103 & 5511.6019 & 7107.30635 & 700.30370 \\
\cline { 2 - 6 } & secondary & 34 & 4500.0000 & 4902.45764 & 840.76455 \\
\hline
\end{tabular}

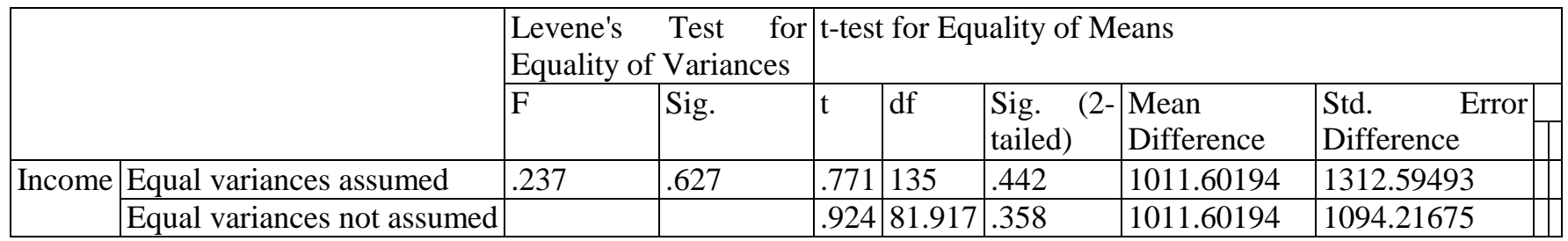


In the one way ANOVA analysis, we reject the null hypothesis at 5\% significant level if the P-value is less than 0.05 , otherwise we accept it. Hence, we conclude that there is significant difference subject to the treatment (x, y and $\mathrm{z})$ at $5 \%$ level of significance (Aliyu, 2011).

Correlation can be defined as the measure of the degree and direction of a linear relationship existing between two or more variables capable of quantitative measurement. The strength of a relationship, or the association, between two or more is typically measured by the coefficient of correlation, whose value ranges from -1 for a perfect negative correlation up to +1 for a perfect positive correlation (Aliyu, 2011). Due to the high number of variables involved in this study, we used multiple correlations. This is achieved using the Karl Pearson formula (Product Movement Correlation)

Regression analysis is a statistical process for estimating the relationships among variables. It includes many techniques for modeling and analyzing several variables, when the focus is on the relationship between a dependent variable and one or more independent variables (or 'predictors'). More specifically, regression analysis helps one understand how the typical value of the dependent variable (or 'criterion variable') changes when any one of the independent variables is varied, while the other independent variables are held fixed. Most commonly, regression analysis estimates the conditional expectation of the dependent variable given the independent variables - that is, the average value of the dependent variable when the independent variables are fixed. Regression analysis is also used to understand which among the independent variables are related to the dependent variable, and to explore the forms of these relationships.(Aliyu, 2011 and Alabi, 2013).A multiple regression model is presented as follows:

$Y=\beta_{0}+\beta_{1} X_{1}+\beta_{2} X_{2}+\beta_{3} X_{3}+\beta_{4} X_{4}+\beta_{5} X_{5}+\beta_{6} X_{6}+\beta_{7} X_{7}+e_{i}$

Where,

$\mathrm{Y}=$ Dependent variable

$\beta 0=$ Intercept

$\beta_{1}-\beta_{7}=$ Regression parameters or coefficients

$\mathrm{X}_{1}-\mathrm{X}_{7}=$ Independent variables

$\mathrm{e}_{\mathrm{i}=}$ Error term

The Duncan Multiple Range Test or Duncan's test, or Duncan's new multiple range test is carried out only when ANOVA yields a significant F value. Hence, Duncan developed a procedure for obtaining all pairwise comparisons among sample means. In general, if the null hypothesis is rejected it means that at least one of the factors differs significantly from the others, and so a method for paired wise comparison is required. Duncan's test is an alternative method for paired wise comparison. It provides significant levels for the difference between any pair of means, regardless of whether a significant $F$ resulted from an initial analysis of variance. Duncan's test differs from the Newman-Keuls test (which slightly preceded it) in that it does not require an initial significant analysis of variance. It is a more powerful (in the statistical sense) alternative to almost all other post hoc methods. This is because the protection level decreases with increasing $r$, which is powerful. That is, there is a high probability of declaring difference when there is actually a difference between population means (Abdi, 2007).

According to Duncan, two population means are significantly different if the absolute value of their sample difference exceeds

$\mathrm{W}=\mathrm{q}(\mathrm{r}, \mathrm{N}-\mathrm{g}) \times \frac{\sqrt{\mathrm{WMS}}}{\mathrm{n}}$.

Where:

W is the Duncan constant

$\mathrm{g}$ is the number of treatments

$\mathrm{n}$ is the number of observations per treatment

$r$ is the range

$\mathrm{N}$ is the total number of observations from $\mathrm{g}$ treatment groups

$\mathrm{q}$ is the Duncan table value

WMS is the within (residual) mean square derived from the ANOVA table

\section{Results and Discussion}

\subsection{Income}

\subsubsection{Comparing income earned by Primary Farmers and Secondary Farmers}

An independent sample $t$ test indicated that there was no significant difference between the income of the primary farmers and that of the secondary farmers thus suggesting that farmers can earn as much income as the white collar jobs for farmers in Jema'a LGA. 
Our a priori expectation was that the income of the secondary farmers would be much higher than that of the primary farmers due to the fact that secondary farmers would be having income from their primary occupation and from the farm also.The proportion of the primary farmers is $74.5 \%$ while that of the secondary farmers is $25.5 \%$.Coulombe and Mckay (2008) found the different sources of income for the household to include income from employment, household agricultural income,non-farm self-employment income, income from rent, income from remittances and other income. The household agricultural income was derived from the sale of cash crops or livestock products, or implicitly from the consumption of home grown agricultural produce. The MSPI of India (2005) found the principal sources of income to include cultivation, farming other than cultivation, other agricultural activities, wage/salaried employment, nonagricultural enterprises, pension, remittances, interest and dividends, and others. It was to be noted that income received from begging, prostitution, etc. would not be considered in the determination of the principal sources of income.

NSA (2012) found that subsistence farming was more common in rural areas having been reported by 40 per cent of the households. This was followed by salaries and/or wages and pension which were reported by 30 and 16 percent of the respondents respectively. The NSA(2012) also found that the main sources of income in the rural areas of Namibia were as follows: Salaries \& wages 30.0\%, Subsistence farming 40.0\%, Commercial farming 0.9\%, Pension 16.1\%, Remittances/ grants $4.5 \%$, Drought/ in kind receipts $2.1 \%$, Business income $5.3 \%$ and Others $1.1 \%$. In contrast, the major sources of family income in the urban areas were: Salaries \& wages $74.3 \%$, Subsistence farming $0.9 \%$, Commercial farming $0.1 \%$, Pension 4.5\%, Remittances/ grants $4.7 \%$, Drought/ in kind receipts 1.0\%, Business income $13.5 \%$ and Others $1.0 \%$.

Table 2: Proportion of General Income of Primary Farmers and Secondary Farmers

\begin{tabular}{|c|c|c|c|c|c|c|}
\hline Income & $\mathrm{N}$ & Minimum & Maximum & Sum & Mean & Std. Deviation \\
\hline $\begin{array}{l}\text { income earned from farm } \\
\text { weekly (primary farmers) }\end{array}$ & 103 & 200.00 & $60,000.00$ & 567695.00 & 5511.6019 & 7107.30635 \\
\hline $\begin{array}{l}\text { income earned from farm } \\
\text { weekly (secondary farmers) }\end{array}$ & 149 & .00 & $60,000.00$ & 715195.00 & 4799.9664 & 6499.88556 \\
\hline $\begin{array}{l}\text { Total incomes (for both } \\
\text { primary and secondary } \\
\text { farmers) }\end{array}$ & 149 & .00 & $60,000.00$ & 1220525.00 & 8191.4430 & 8147.06257 \\
\hline
\end{tabular}

Source: Field Survey Data, 2016

Table 2 shows the proportion of farmer's income for primary farmers. It shows that the income for primary farmers is $79.38 \%$, while the income for the secondary farmers is $20.62 \%$.

\subsection{Expenditure}

Table 3 shows the result of the expenditure pattern for the primary farmers as well as for the secondary farmers. There is no expenditure for secondary farmers in respect of social, education and health. Both categories of farmers had uniform minimum expenditure. By way of ranking, the highest expenditure for primary farmers is transport; followed by house maintenance and education. The no expenditure observed for social, education and health categories of expenditure could have been for the following reasons. In the case of social, the explanation could be that their level of participation in social activities was quite low. These secondary farmers may have had their children in staff schools where they work and may not have paid school fees or had the school fees being deducted directly from their salaries. In the case of health, they may have been registered under the National Health Insurance Scheme (NHIS). In which case, their health needs including that of their families were being met by NHIS. On the other hand, the highest expenditure is farm followed by house maintenance and food. It is not surprising that food is ranked 5 among the primary farmers. Food was ranked fifth due likely to the fact that primary farmers depended on own farm production more than the secondary farmers. The primary farmers were full time farmers. The expenditure on food was not unexpected as most farm households do not usually produce every food item they require on their farms.Agular and Hurst (2005) for example provided empirical evidence documenting the importance of home consumption. They posited that given home consumption, they concluded that certain expenditures, particularly expenditure on food are poor proxies for actual household consumption which mark the extent to which indivisuals smooth consumption in practice. In Nigeria,Banwat et al.(2012) in a study on factors affecting household food security in a rural community in North Central Nigeria reported that $66.2 \%$ of the studied households grew most of their consumed food on their farmlands while $43.8 \%$ of the households spent between $25-50 \%$ of their monthly income on feeding their households. 
Similarly, Manza (2014) found in Southern Borno State among PROSAB farmers and non PROSAB farmers that their major source of food for their households was own production which was $71.1 \%$ and $61.3 \%$ respectively.

The second major source of food for their households was food purchased from the market which was $25.1 \%$ and $28.9 \%$ for PROSAB farmers and non PROSAB farmers respectively.

Table 3: Expenditure Pattern for Primary Farmers and Secondary Farmers

\begin{tabular}{|l|l|l|l|l|l|l|l|l|}
\hline Primary Farmers & $\mathrm{N}$ & Minimum & Maximum & Sum & Mean & Std. Deviation & Rank \\
\hline Food & 111 & .00 & 27900.00 & 530425.00 & 4778.6036 & 3578.71594 & 5 \\
\hline Social & 111 & .00 & 10000.00 & 55410.00 & 499.1892 & 1661.78991 & 8 \\
\hline Education & 111 & .00 & 49000.00 & 262700.00 & 13826.32 & 14984.987 & 3 \\
\hline Health & 111 & .00 & 11000.00 & 37850.00 & 340.9910 & 1421.65394 & 7 & \\
\hline Transport & 111 & .00 & 85000.00 & 232050.00 & 2090.5405 & 8667.28046 & 1 & \\
\hline Farm & 111 & .00 & 42000.00 & 190300.00 & 1714.4144 & 6202.37267 & 4 \\
\hline House & 111 & .00 & 54250.00 & 303605.00 & 2735.1802 & 7100.33619 & 2 & \\
\hline Miscellaneous & 111 & .00 & 25000.00 & 178665.00 & 1609.5946 & 3456.24673 & 6 \\
\hline
\end{tabular}

Secondary farmers

\begin{tabular}{|l|l|l|l|l|l|l|l|}
\hline & $\mathrm{N}$ & Minimum & Maximum & Sum & Mean & Std. Deviation & Rank \\
\hline Food & 40 & .00 & 12250.00 & 230990.00 & 5774.7500 & 3036.14823 & 3 \\
\hline Transport & 40 & .00 & 8000.00 & 43900.00 & 1097.5000 & 2086.03261 & 5 \\
\hline Farm & 40 & .00 & 2300.00 & 2300.00 & 57.5000 & 363.66193 & 1 \\
\hline House & 40 & .00 & 21150.00 & 64770.00 & 1619.2500 & 3200.36487 & 2 \\
\hline Miscellaneous & 40 & .00 & 8250.00 & 44850.00 & 1121.2500 & 1407.80278 & 4 \\
\hline
\end{tabular}

Source: Field Survey Data, 2016

Sethi and Pradha(2012) say in Western Odisha of India that consumption expenditure to be increasing due to increase in urbanization, breaking up of traditional joint family system,desire for quality food, lack of time which translated to an increase need for convenience. They added that increasing the number of working women,rise in the per-capita income in forcible situations of other dominants, changing lifestyles and increasing level of affluence of the surroundings with a lack of the saving attitude and appropriate awareness brought significant changes in the expenditure patterns among the rural communities.

Busumatary (2015) states that consumption expenditure in the Bodo tribal area basically depends on the amount of income hey can derive by selling their labour in the agricultural sector. He also found that that the level of consumption expenditure of the tribal people in the rural areas basically depended directly or indirectly on the amount of output they could produce from their farm lands. As such,their level of consumption was generally determined by the subsistent agricultural production.

Table 4: Percentage Comparison of Expenditure Patterns of Primary Farmers and Secondary Farmers

\begin{tabular}{|l|l|l|l|l|}
\hline & Primary \% & Secondary \% & T-test value & Sig. value \\
\hline Food & 29.616 & 59.717 & -1.568 & 0.119 \\
\hline Social & 3.094 & 0.00 & 3.156 & 0.002 \\
\hline Education & 14.668 & 0.00 & 4.022 & 0.001 \\
\hline Health & 2.113 & 0.00 & 2.527 & 0.013 \\
\hline Transport & 12.956 & 11.349 & 0.717 & 0.475 \\
\hline Farm & 10.625 & 0.60 & 2.801 & 0.006 \\
\hline House & 16.952 & 16.745 & 0.958 & 0.340 \\
\hline Miscellaneous & 9.976 & 11.545 & 0.867 & 0.388 \\
\hline
\end{tabular}

Source: Field Survey Data, 2016

Table 4 shows that the difference in expenditure between primary farmers and secondary farmers which is significant at $1 \%$ level of significance for social, education, health and farm work. In the contemporary world, the consumption habits and pattern are determined by a complex set of socio-economic, cultural, religious, psychological, and environmental factors. This was why Busumatary (2015) asserted that the consumption pattern of a community distinctly reveals its financial position as well as its standard of living,poverty level and human development. Hence, the annual family expenditure of a household is an important barometer of the economic status and material well-being of a family. 


\subsection{Comparing total expenditure with total income}

Comparing total expenditure with total income as in Table 5, it was observed that there is a significant difference between total income and total expenditure. Taking a good look at the paired sample statistics, we clearly see that the mean for total income is higher than that of total expenditure. The difference in expenditure between the primary and secondary farmers was significant at $1 \%$ probability for social, education, health and farm work, This could have been due to the existence of higher income by the primary farmers than the secondary farmers which could have led to higher expenditure on these categories. Secondly, this could be a reflection of the priorities attached to these expenditures by primary farmers. Hence, we can conclude that the farmers in Jema'a LGA spend more than they earn. The finding suggests that the farmers did not declare all of their income. This was probably why Busumatary (2015) also shows that most of the households among the Bodo tribe made more expenditure than their income. Mears and Biyase (2010) also assert that "not surprising, many households have a higher expenditure per month than their income". This was because they found that some of the respondents refused to divulge their income and that in some cases it was obvious that the income was too low to afford the expenditure per month.

\begin{tabular}{|c|c|c|c|c|c|c|c|c|c|}
\hline \multicolumn{10}{|c|}{ Table 5: Comparison of Income and Expenditure of all Farmers Paired Samples Statistics } \\
\hline & & & Mean & $\mathrm{N}$ & \multicolumn{2}{|c|}{\begin{tabular}{l|l} 
Std. Deviation \\
\end{tabular}} & \multicolumn{3}{|c|}{ Std. Error Mean } \\
\hline \multirow[t]{2}{*}{ Pair 1} & \multicolumn{2}{|c|}{ Total expenditure } & 14644.0604 & 149 & \multicolumn{2}{|c|}{22772.20075} & \multicolumn{3}{|c|}{1865.57138} \\
\hline & Total income & & 8191.4430 & 149 & \multicolumn{2}{|c|}{8147.06257} & \multicolumn{3}{|c|}{667.43337} \\
\hline \multicolumn{10}{|c|}{ Paired Samples Test } \\
\hline & & \multicolumn{5}{|c|}{ Paired Differences } & \multirow[t]{3}{*}{$\mathrm{t}$} & \multirow[t]{3}{*}{ df } & \multirow{3}{*}{$\begin{array}{l}\text { Sig. } \\
(2- \\
\text { tailed })\end{array}$} \\
\hline & & \multirow[t]{2}{*}{ Mean } & \multirow[t]{2}{*}{\begin{tabular}{|l|} 
Std. \\
Deviation
\end{tabular}} & \multirow[t]{2}{*}{$\begin{array}{l}\text { Std. } \\
\text { Error } \\
\text { Mean }\end{array}$} & \multicolumn{2}{|c|}{$\begin{array}{ll}95 \% & \text { Confidence } \\
\text { Interval of the } \\
\text { Difference }\end{array}$} & & & \\
\hline & & & & & Lower & Upper & & & \\
\hline $\begin{array}{l}\text { Pair } \\
1\end{array}$ & $\begin{array}{l}\text { Total expenditure - } \\
\text { Total income }\end{array}$ & 6452.618 & \begin{tabular}{l|l}
8 & 24624.435
\end{tabular} & 2017.312 & 2466.161 & 10439.074 & 3.199 & 148 & .002 \\
\hline
\end{tabular}

Source: Field Survey Data, 2016

Looking at the spending habit of farmers in Jema'a, we categorized their expenditure into 8 groups namely: food, social, education, house, transport, farm, health and miscellaneous expenditures. These expenditures were analyzed using ANOVA to ascertain whether there is a significant difference between the various categories of expenditure. The result showed that at 5\% significant level, there is a significant difference between the expenditure for the various categories. The inability of the respondents to provide detailed information is not uncommon as respondents are sometimes suspicious of the objectives for which certain information was being solicited in terms of what it would be used for. There are usually fears that the information on income may be used for tax purposes.

Table 6: ANOVA for expenditure

\begin{tabular}{|c|c|c|c|c|c|}
\hline \multicolumn{6}{|l|}{ SMEAN(Amount) } \\
\hline & Sum of Squares & $\mathrm{df}$ & Mean Square & $\mathrm{F}$ & Sig. \\
\hline Between Groups & 1910112340.580 & 7 & 272873191.511 & 11.797 & .000 \\
\hline Within Groups & 27387390233.280 & 1184 & 23131241.751 & & \\
\hline Total & 29297502573.859 & 1191 & & & \\
\hline
\end{tabular}

Source: Field Survey Data, 2016

Furthermore, a Duncan multiple range test was performed to see which of the categories enjoy the better share of the expenditure. From the lowest to the highest in that rank of the Duncan table, we observed that food carries the highest share of the expenditure followed by education, transport, farm work, house, health, miscellaneous, social respectively. 
Table 7: Duncan Multiple Range Test for Expenditure by the Farmers

\begin{tabular}{|l|l|l|l|l|l|l|}
\hline Expenditure & $\mathrm{N}$ & \multicolumn{5}{|l|}{ Subset for alpha =0.05 } \\
\cline { 3 - 7 } & & 1 & 2 & 3 & 4 & 5 \\
\hline Social & 149 & 452.7954 & & & & \\
\hline Miscellaneous & 149 & & 1952.5946 & & & \\
\hline Health & 149 & & 2117.3145 & 2117.3145 & & \\
\hline $\begin{array}{l}\text { House } \\
\text { Maintenance. }\end{array}$ & 149 & & 2622.8841 & 2622.8841 & 2622.8841 & \\
\hline Farm Work & 149 & & 3109.6257 & 3109.6257 & 3109.6257 & \\
\hline Transport & 149 & & & 3284.4586 & 3284.4586 & \\
\hline Education & 149 & & & & 3557.3642 & \\
\hline Food & 149 & & & & & 5079.6309 \\
\hline Sig. & 1.000 & .057 & .055 & .128 & 1.000 \\
\hline Source: Field Survey Data, 2016 & & & & \\
\hline
\end{tabular}

Note: Means for groups in homogeneous subsets are displayed.

a. Uses Harmonic Mean Sample Size $=149.000$.

Table 8: Pearson Correlation between income and expenditure

\begin{tabular}{|l|l|l|l|l|l|l|l|l|l|}
\hline \multicolumn{2}{|c|}{} & House & Miscellaneous & Farm & Transport & Educational & Health & Social & Food \\
\hline $\begin{array}{l}\text { Total } \\
\text { income) }\end{array}$ & $\begin{array}{l}\text { Pearson } \\
\text { Correlation }\end{array}$ & .31 & .17 & .71 & .07 & .13 & .03 & .22 & .65 \\
\cline { 2 - 10 } & Sig. (2-tailed) & .075 & .155 & .048 & .098 & .085 & .019 & .390 & .036 \\
\cline { 2 - 10 } & $\mathrm{N}$ & 149 & 149 & 149 & 149 & 149 & 149 & 149 & 149 \\
\hline
\end{tabular}

Source: Field Survey Data, 2016

Table 9: Regression Analysis result of Income and Expenditure

\begin{tabular}{|c|c|c|c|c|c|c|c|c|c|c|}
\hline \multicolumn{11}{|c|}{ Coefficients $^{\mathrm{a}}$} \\
\hline \multirow{2}{*}{\multicolumn{3}{|c|}{ Model }} & \multicolumn{4}{|c|}{ Unstandardized Coefficients } & \multirow{2}{*}{\multicolumn{2}{|c|}{$\begin{array}{l}\text { Standardized Coefficients } \\
\text { Beta }\end{array}$}} & \multirow[t]{2}{*}{$\mathrm{t}$} & \multirow[t]{2}{*}{ Sig. } \\
\hline & & & \multicolumn{2}{|l|}{$\mathrm{B}$} & \multicolumn{2}{|c|}{ Std. Error } & & & & \\
\hline \multirow[t]{2}{*}{1} & \multicolumn{2}{|c|}{ (Constant) } & \multicolumn{2}{|c|}{17840.519} & \multicolumn{2}{|c|}{3017.823} & & 5.912 & .000 \\
\hline & \multicolumn{2}{|c|}{ Total Income } & \multicolumn{2}{|l|}{0.192} & \multicolumn{2}{|l|}{.258} & \multicolumn{2}{|l|}{0.065} & -.744 & .045 \\
\hline \multicolumn{11}{|c|}{ a. Dependent Variable: Total.expenditure } \\
\hline \multicolumn{11}{|c|}{ Model Summary } \\
\hline \multicolumn{2}{|l|}{ Model } & \multicolumn{2}{|l|}{$\mathrm{R}$} & \multicolumn{2}{|c|}{ R Square } & \multicolumn{2}{|c|}{ Adjusted R Square } & \multicolumn{3}{|c|}{ Std. Error of the Estimate } \\
\hline \multicolumn{2}{|l|}{1} & $.65^{a}$ & & \multicolumn{2}{|c|}{.423} & \multicolumn{2}{|c|}{.403} & \multicolumn{3}{|l|}{23866.56414} \\
\hline
\end{tabular}

Source: Field Survey Data, 2016

Note: a. Predictors: (Constant), Total.income

\subsection{Correlation test analysis between total income $\&$ various categories of expenditures}

This test was conducted to show the strength of relationship that exists between total income and various expenditures. The strength of relationship helped to ascertain which of these expenditures is likely to increase as the total income increases or decreases and also to whatextend such change is likely to occur. Hence we can also compare the responsiveness to change. For example, the correlation coefficient between total income and house expenditure is 0.31 (sig. $=0.075)$. This is an indication that there is a weak relationship between total income and housing expenditure. Hence, an increase in total income may not necessarily increase the house expenditure. The correlation coefficient between total expenditure and miscellaneous expenditure is very weak at 0.17 (sig. 0.155 ). This shows that an increase in total income may not necessarily affect the miscellaneous expenditure. Furthermore, the relationship between total income and transport expenditure is very weak, at 0.07 (sig. $=0.98)$. This shows that if income increases, transport expenditures may not be affected much.

More so, the correlation coefficient between total income and education is 0.13 (sig. $=0.85$ ). This is an indication that there is a very weak relationship between total income and educational expenses. Farmers in Jema'a LGA can be concluded to be not literateas a result and do not wish to spend much on the education of their children. Health-wise, there is a very weak relationship between total income and health expenditures, at 0.03 (sig. $=0.091$ ). Farmers here do not wish to spend much on their healthbecause they value native and herbal method of treatment which is readily available around them and perhaps cheaper. 
The correlation coefficient between total income and Social expenditure is $0.22 \quad($ sig. $=0.390)$. This connotes that there is a weak relationship between total income and social expenditure. This could also mean that as income increases, social expenditure may not necessarily increases.

However, the researchers observed that there is a very strong correlation coefficient between total income and farm expenditure which is 0.71 ( sig. $=0.48$ ). This implies that an increase in total income will as well increase the farm expenditure. Hence, the farmers in Jema'a LGA will invest more on their farmlands if their income or revenue increases. Similarly, the correlation between total income and total expenditure for food is 0.65 (sig.036) which suggests that the relationship between income and expenditure on food is strong. This means that with an increase inincome, the expenditure on food will increase.

It can be said therefore that total income has a strong relationship with farm and food expenditures. This is a clear signal that an increase in the farmers' income will also increase farm and food expenditures. This shows the farmers' readiness to invest in farming.

\subsection{Regression Analysis}

The regression analysis gave the following result. The constant, which is approximately $\$ 17,840.52$ indicates the average amount of money farmers earn yearly. The slope coefficient, which is 0.192 shows that for every unit increase in income, expenditure is expected to increase by 0.192 . $\mathrm{R}$ squared is 0.423 i.e. $42.3 \%$ which means total expenditure accounted for only $42.3 \%$ of the income received.

\section{Conclusion}

It was that the income for primary farmers was lower than that of secondary farmers. However, the difference in income was not found to be significant at 5\% significant level. The research also shows that consumption expenditure in Jema'a LGA basically depends on the amount of income they can derive from selling of farm produce and off farm activities for those farmers who had agriculture as a primary occupation (primary farmers) while for the farmers who have agriculture as a secondary occupation (secondary farmers), their source of income were their primary occupation and sale of farm produce. Most of the households had more expenditure than their declared income suggesting that all of their income was not declared or that the undeclared income might have been shared.

\section{Recommendations}

1. For all categories of farmers, a bulk of the income came from the output they could produce from their farm lands. Therefore, government at the federal level should consider the provision of minimum prices for some of the major crops grown to enable the farmers earn higher incomes.

2. For both categories of farmers, food was the major source of expenditure ( $29.6 \%$ for primary farmers and $59.7 \%$ for secondary farmers). In order to minimize expenditure on food there is therefore the need for the farmers to increase their cultivation of food crops.

3. The study shows that agriculture is the main source of livelihood of the sampled households suggesting that government at the local government and state government levels should aim towards increasing agricultural productivity and production. This is necessary if farm income, living standards, nutrition, education, and health of individual members of the household can be improved.

4. There exists still much to be done by the people through community work. As a result, the Jema'a local government council and Kaduna State government should improve on infrastructure such as roads, markets, irrigation facilities, health centers, access to farm inputs like inorganic fertilizer, improved seeds and seedlings, agrochemicals and storage facilities as a way of improving the incomes of the farmers through the farm.

\section{References}

Abdi, H. (2007). Bonferroni and Sidak Corrections for Multiple Comparisons. In N.J. Salkind (Ed.): Encyclopedia of Measurement and Statistics. Thousand Oaks (CA): Sage. Pp.103-107

Abdulazeez, S.A, Onah, H.O. and Umar, S.S. (2002).Fundamentals of Statistics.Published by Eskodab Ventures (Printing and Publication) W4, Ahmadu Bello Way, Kaduna, Nigeria.

Adedotun, P. (1978). Nigeria's Public Consumption Expenditure. The Journal of Economics and Social Studies, 20(3): 12-16.

Agular, M. and Hurst, E. (2005).Lifecycle Prices and Production.University of Chicago Working Paper.Pp.1-4.

Alabi, O.O. (2013). Fundamental Statistics and Experimental Designs.Joyce Graphic Publishers. Kaduna - Nigeria. Pp.89-96, 103-108, 161-167. 
Alimi, R.S. (2013). "Keynes Absolute Income Hypothesis and Kuznets Paradox", MPRA Paper no.49310, http://mpra.ub.unimuenchen.de/49310/.

Aliyu, U.A. (2011). Statistical Methods for Biometrics and Medical Research.Published by Millenium Printing and Publishing Company Ltd, Kaduna, Nigeria.

American Heritage Dictionary of the English Language (2011). Income Houghton Mifflin Harcourt Publishing Company,

Banks, J. and Leceister, A. (2014 ).Expenditure and Consumption. Institute for FiscalStudies.

Basumatary, S. (2015). An Analysis of Consumption Expenditure Pattern among the BodoTribe: A Case Study International Research Journal of Interdisciplinary \&Multidisciplinary Studies (IRJIMS). ISSN: 2394-7969 (online).Volume, Issue V June 2015, Pp.42-48 (http://www.irjims.com)

Banwat,M.E.,Lar,L.A.,Dakum,L.B.,Igoh,C.S.,Daboer, J.C. and Ogbonna, C.(2012). Factors Affecting Household Food Security in A Rural Community in North Central Nigeria. International Journal of Community Research.Vol 1(1).P. 23-29.

Coulombe, H. and Mckay, A. (2008). The Estimation of Components of Household Incomes and Expenditures: A Methodological Guide on the three rounds of the Ghana Living Standards Survey, 1991/1992,1998/1999 and 2005/2006.

Dauda, R.O. (2003). Poverty, Inequality and Socio-economic Development Policies in Nigeria: Issues in Money, Finance and Economic Management in Nigeria. In Oluwatayo, O.F. andOlasupo, A. (eds). Essays in Honor of Professor ObasanmiOlakampo.University of Lagos, Lagos.

Deaton, A. (2001). Understanding Consumption, Clarendo Press, London

Flavin, (2003). Excess Sensitivity of Consumption of Current Income: Liquidity Constraint or Myopia. Canadian Journal of Economics.

Investopedia (http://www.investopedia.com/terms/i/income.asp.whatisincome. accessed on the 4th August, 201

International Fund for Agricultural Development (IFAD) (2001).Rural PovertyReport 2001.The Challenges of Enduring Rural Poverty.

Manza, E.A.G.(2014).Impact of Promoting Sustainable Agriculture on Food Security, Farm Income and Livelihoods in Southern Borno State, Nigeria. A PhD thesis submitted to the Post Graduate School, Ahmadu Bello University, Zaria. Pp. 108-110.

Mears, R. and Biyase, M. (2010).Comparison of the Income and Expenditure Patterns of Selected Rural Communities in the Nwanedi River Basin with Poor Townships in Soweto.Journal of Public Administration.Vol.45 No.3 September.

Ministry of Statistics and Programme Implementation of the Government of India(MSPI)(2005). NSS Report No.495:Consumption Expenditure of Farmer Households.

Namibia Statistical Agency (NSA) (2012).Namibia Household Income and Expenditure Survey(NHIES) 2009/2010. Pp.54-55.

National Bureau of Statistics (NBS) (2010).Sources of Income for Households in Nigeria.

National Population Commission (2006).Population Census, Abuja, Nigeria.

Nwabueze, J.C. (2009). Causal Relationship Between Gross Domestic Product and Personal Consumption Expenditure of Nigeria. African Journal of Mathematics and Computer Science Research. 2(8): 179-185.

Ofwona, A.C. (2013). "An Estimation of the Consumption Function for Kenya Using Keynes Absolute Income Hypothesis for the Period 1992-2011", Journal of Emerging Trends in Economics and Management Sciences (JETEMS), 4 (1):100-1005

Ojeleye, O.A. (2015). Analysis of Farm Household and Community Food Security in Kaduna State, Nigeria. A Ph.D thesis submitted to the Post Graduate School of Ahmadu Bello University, Zaria.Pp.23.

Sethi,N. and Pradha,H.K. (2012). Patterns of Consumption Expenditure in Rural Households of Western Odisha of India: An Engel Ratio Analysis. OIDA International Journal of Sustainable Development, Vol.05,No.04. Pp.107-120.

Uwajaren, G. (1977). Specification and Estimation of an Economy-wide Macro-econometric model of Nigeria.Nigerian Journal of Economics and Social Studies, 19(2); 20-25.

Wikipedia on Income. Accessed on the 4th August, 2016

Zeldes, F.(2005). Consumption and Liquidity Constraints: An Empirical Investigation. Journal of Political Economy, 2(3): 16-20. 